\title{
THE MAN - MACHINE TYPE SYSTEMS MODELING APPROACH
}

\section{METODYKA MODELOWANIA UKLADÓW TYPU CZLOWIEK - MASZYNA}

\author{
Zbigniew SMALKO' ${ }^{1}$, Janusz SZPYTKO
}

(1) Air Force Institute of Technology, Warszawa, Poland (2) AGH University of Science and Technology, Krakow, Poland E-mails: (1) zbigniew.smalko@itwl.pl, (2) szpytko@agh.edu.pl

\begin{abstract}
The subject of this paper deals with selected usable characteristics of man machine systems described by the selected basic attributes. The paper is describing also major objectives of safety engineering, based on the system approach, understanding the structure of safety management system, including the human factor, and all interrelationships between the system components. The part of the paper is example of safety engineering implementations in practice. Copyright (C) 2008 Journal of KONBiN.
\end{abstract}

Keywords: man-machine set, availability, safety, reliability

Streszczenie. Przedmiotem artykułu jest modelowanie złożonych układów technicznych typu człowiek - maszyna. Istotą modelowania układu z uwagi na sformułowany cel działania jest wybór opisującego zbioru właściwości, które zostały szczegółowo opisane. $\mathrm{W}$ artykule uwagę zwrócono ponadto na zagadnienie inżynierii bezpieczeństwa obejmującej między innymi strukturę układu typu człowiek - maszyna z uwzględnieniem ich potencjałów oraz relacji pomiędzy wyróżnionymi elementami i otoczeniem. Przedstawiono ponadto przykład kształtowania bezpieczeństwa układu typu człowiek maszyna w transporcie.

Słowa kluczowe: układ człowiek-maszyna, nieuszkadzalność, bezpieczeństwo, niezawodność 


\section{Introduction}

The object of paper is usable characteristics of the man - machine system, where the man can act both a decision - maker or operator position. The psychophysical efficiency of man depends on undertaking faultless decisions, as well as on correct controls and skilful machine operating.

The operation tasks realization have place in the man - machine - surroundings sets. Machine was designed to man's aid, both from energetically and information side, which are expressed in the integrated so-called mechatronics sets operating in the surroundings that include the techno-zone (resulting human activities) and natural environment.

We can recognize that the following operation sequences: the man has an effect on the machine; the machine has an effect on surroundings (processing, displacements, etc.). The positive result of the above activity we will recognize as done by man, supported through machine and desirable environment reaction. It is desirable, that influences of man - machine set at the surroundings must be effective and harmless. The above results with selection of suitable machine and suitable operator to realization of definite task (activity).

The effective and safe realization of described task (activity) by the man - machine - surroundings set in practice not always is possible, because the following events can occur:

- the positive man influences on machine can accompany undesirable reactions coming from machine, which are harmful for man, e.g.: vibrations, noise,

- the positive machine influences on surroundings can accompany undesirable reactions coming from surroundings, which are harmful for machine, surroundings and men, e.g.: conflicts and collisions with elements belong to surroundings on micro- and macro- scales,

- the positive surroundings secondary influences on machine can accompany undesirable reactions, which are harmful for man, e.g.: his senses of sight, hearing and smell.

The described factors, together or separately, cause with unfavorable changes of technical states of any elements the man - machine set. The unfavorable task realization circumstances are mostly identified with hazards affecting the man and machine. They are coming both from external and internal forcing factors, which have fatigue, wear, or/ and ageing character [Avizienis et al, 2000; Gottl Ottilienfeld, 1932; Jaźwiński \& Borgoń, 1989; Mazur, 1961; Puszkin, 1971; Smalko, 1987; Titus et al, 1995; PN-77/N-04010].

\section{Hazards in Man - Machine - Surroundings Set}

In menaced man - machine - surroundings set it is possible to distinguish the following technical states: fit for use, partial fit for use, partial unfit for use, critical unfit for use and total unfit for use (Fig. 1). 


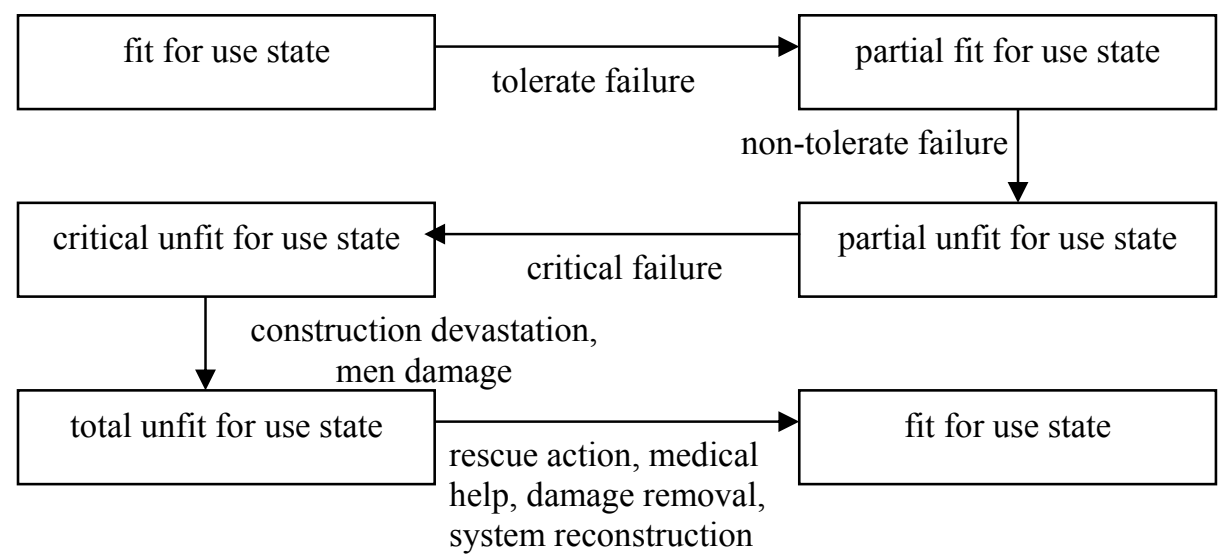

Fig. 1 The unsafe graph of man - machine set

The system fit for use technical state characterizes with lack of damages, non-cross acceptable operation state of the system, operator feels safe and system is acting correctly. The system moves to the partial fit for use technical state we identify with tolerable damage. The degradation prevention and counteraction of the machine depends on: technical services, losses completing, system technical state monitoring, and user insurance after-effects of incidents, damages and losses.

The system partial fit for use technical state characterizes with tolerable of damages, non-cross the acceptable operation state of the system, operator feels light threat, and machine can correctly executing ordered task yet. The destructive process of the system has been started. The system moves to the partial fit for use technical state we identify with un-tolerable partial damage. The degradation prevention and counteraction of the machine depends on self-acting decomposition of existing excesses.

The system partial unfit for use technical state characterizes with untolerable partial of damages, the acceptable operation state of system is exceed and limiting level is reached, operator feels light threat, and machine is not correctly executing ordered task. Also it is possible to identify first symptoms of arise process of damages and losses, moreover threats are occurring and any accident is possible. The system moves to the critical unfit for use technical state we identify with critical damage. The degradation prevention and counteraction of the machine depends on starting the security units and caution via alarms.

The system critical unfit for use technical state characterizes with critical damages, the acceptable operation state of the system is exceed and critical level is reached, the harmful factors are acting at the operator and machine is not correctly executing ordered task or is a subject stoppage (stops to act and to execute task). Also it is possible to identify first symptoms of arise process of damages and losses. The system moves to the total unfit for use technical state we identify with 
machine damage and men injuring. The degradation prevention and counteraction of the machine depends on slowing down and interruptions the process of formation of damages and losses, as well as on alarming the surrounding.

The system total unfit for use technical state characterizes with extensive destructions, damages and losses, the critical level of the technical state of the system is crossed, the operator is injured and machine loses operation features and the realization of task is not more possible. The above results within considerable damages and losses. The system returns to fit for use technical state depend on renovation (or interchange) the total machine, men's' medical help, damages and losses results compensation. The degradation prevention and counteraction of the men - machine set depends on actuating the rescue system, as well as medical and technical services. From here we can recognize important problem the choosing to defined tasks realization proper devices. Therefore we will occupy oneself with description the selected usable features of the machine and also some man's features (operator and decision-maker).

\section{Selected Operation Features of Man - Machine Set}

Main operation features and attribute of man - machine set enclose: adequacy, dependability, safety, durability, and effectiveness (Fig. 2).

Adequacy, is the feature of the man - machine set, describing in multiaspect way preparation this set to executing described tasks in the reference or extremely conditions in operation condition. The adequacy as a joint feature of the device is described by four collections: functionality, ergonomics, compability and operability.

Adequacy, is the feature of the man - machine set, describing in multiaspect way preparation this set to executing described tasks in the reference or extremely conditions in operation condition. The adequacy as a joint feature of the device is described by four collections: functionality, ergonomics, compability and operability.

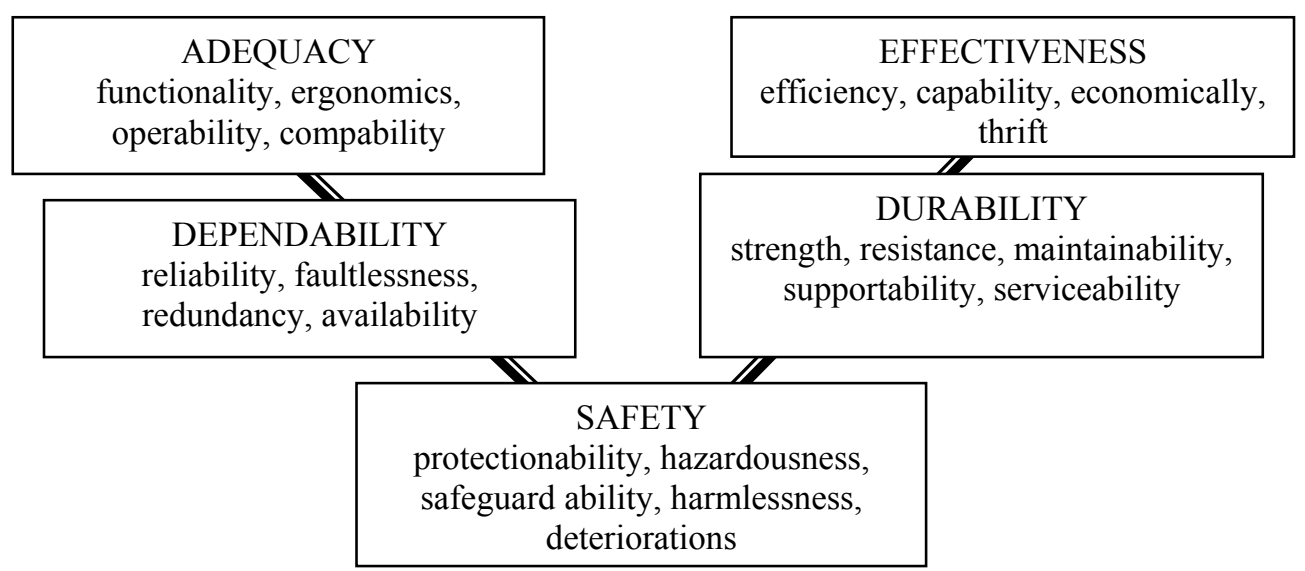

Fig. 2 The methodology of risk evaluation of transport project 
The feature of the machine describing her convenience of structure solution so called configure-ability expresses functionality. Configure ability assures device coverage and the programmability.

Ergonomics is expressed by the feature of the machine describing her adaptation to antropotechnical and psychophysical feature of the man. The above is possible to achieve via user-friendly solutions, adequate structure solutions, and man machine interfaces.

Compability is a feature of the machine describing adaptation of her working organ structure solution to different technical objects, as well as to existing infrastructure feature.

Operability is expressed by the feature of the machine describing her structure solution which cause with easiness of machine use under operation (navigating, manipulate and maneuver). In this is possible to achieve: getting the response time of working organ which are resulting the control signals (exact and quick answer), control simplicity (simple way steering), the accessibility (access to lever and buttons), good visibility of panels and device technical state indicators, position of the device inside the working space, etc.

Dependability describing features of the man - machine set to executing attributed functions, in definite time and in definite conditions of use. Executed activities are safety, effective and without any breaks during operation. Dependability is a joint feature of man - machine set, described through reliability, redundancy, faultlessness and availability:

- reliability, feature of the machine describing her ability to working other breakdowns, in the set time and the settled circumstances,

- redundancy, feature describing total booking arrangement of the man machine set, which creates the possibility of tolerance of the machine damages and the man errors. The redundancy results with existing in the man - machine set excesses the following types: structural, functional, time and information,

- faultlessness, the man's feature (decision-maker, operator) describing his ability to correct undertaking the decision about activity starting with support of the machine and to correct machine controlling, with taken under the consideration the possible changes of the device technical state and state of the surroundings,

- availability, total feature of the man - machine set describing his ability to provide the machine in required technical state assuring her disposability.

Safety is expressing the total feature of the man - machine set, describing the set preparation to avoidance of threats and the risks in movements and in the state of waiting (stand). The more preciously analyzed of this set can be described with the following collections - protectionability, hazardousness, harmlossness, safeguard ability and deteriousness:

- protectionability - feature of the machine describing her preparation to operator protection, the crew, passengers or loads, before results of external and internal possible hazards. These are achieved by strengthener construction, as well as in-build to the machine the special protecting devices (the seat belt, Antilock 
Breaking System, etc.) and servomechanisms. The above is also possible to achieve by use of information and functional excesses enabling to operation parameters tolerance (critical damages),

- hazardousness - is a feature of the man - machine set describing preparation the man's and susceptibility control devices to quick maneuvering, accelerations changing, speed moving and machine slow down. The overlooked benefits are: machine operation with damage-less and avoidance of possible conflicts with surroundings,

- harmlessness - the feature of the man - machine set describing his preparation to limitation of harmful influences on natural environment,

- safeguard ability - the feature of the machine - surroundings set describing warning system and blocking unit, which make not possible access to the set by unauthorized persons,

- deteriorations - the feature of the man - machine - surroundings set describing correctness of cooperation of set elements during elimination and neutralization possible damages and losses.

Durability of machine is the feature that expressed with the limiting period of use of machine (service life), which e.g. results with not acceptable hardiness of elements against acting factors. The critical life period of the machine is also a part of expenses spend and linked with maintaining oriented to system availability. The more preciously analyzed of the machine can be described with four collections: strength, resistance, maintainability, supportability and serviceability:

- strength - is the feature describing ability to constructional material of machine to counteraction of degradation till moment of crossing of admissible usable burdens,

- resistance - is the feature describing ability to constructional material of machine to counteraction of degradation from influence of external factors,

- maintainability - the feature of machine describing her susceptibility to repair in appointed period of time,

- $\quad$ supportability - the feature describing the machine preparation to provide her in required technical condition during designed period of exploitation, with support services, maintaining, and condition monitoring,

- serviceability - the feature of the man - machine - surroundings set describing the assurance of different services and inspection possibility realization focusing on the machine, through exploitation lifecycle period.

Effectiveness expressing the feature describing ability of the man - machine set to safe energy consuming, as well as rational utilization of other material and financial expenditures related to the described operation activities. The effectiveness can be described by four collections - efficiency mostly expressed via energy, capability, economically and thrift:

- energetically efficiency - is the machine feature describing her useful energy processing,

- capability - the feature describing ability of machine to achieve overlooked results that are a subject of expressing by measurable economical factors, 
- economically - the feature of the man - machine set expressed by rational use of money for described task realization,

- thrift - the feature describing the man's skill to realization operation tasks within thrifty principles, including machine service life, object and financial outlays.

\section{Safety Engineering}

With increasing the automation level of technical systems and devices, more and more attention has been focuses on problems of safety and reliability (Smalko \& Szpytko, 2003; Szpytko, 2004a; Smalko, 2005; Smalko, 2008; Szpytko, 2007a). More information properly related to the safety it is possible to achieve from publications (Aven \& Vinnem, 2007; Jaźwiński \& Ważyńska-Fiok, 1993; Sklet, 2006), and to reliability from the example references (Tobias and Trindade, 1986; Mourbray, 1991; Borgoń et al, 1992; Elsayed, 1996; Saleh \& Marais, 2006) and standards. The safety can be a subject of control, and its required level can be obtain by in-build security systems, which enables restraining work in critical point. The critical state of any technical device could arise from the loss of operation abilities after exceeding the allowable values. Reliability of the object/ device includes the proper features of a device and the system of detecting and removing the failures, which occurred during utilization. The failures are the results of operation and exceeding critical values of the device, and their changes are mostly random. The above results with new today problems in engineering practice (Szpytko, 2007a), so-called safety engineering, waiting for description and solving, for example:

- investigation of results of lack memory of the technical systems including objects/ devices,

- cause - results type approach to investigation of damages in arrangement of possible states of the system,

- correlation of system safety and reliability,

- integrated perception the life phases of object/ device from regard the safety and reliability aspects,

- follow-up systems and objects/ devices structures integration.

The today modern technical and organizational systems have become so large and sophisticated that the safe management is nearly infeasible and exceeds capability of organizations that are established to be in charge of economy, industry and transport and others. The major objective of safety engineering, based on the system approach, is to understand the structure of safety management system, including the human factor, and all interrelationships between the system components. Major issues on safety engineering of any business include: selection of suitable tolerance zones of selected key operation parameters of the system, taking the human factor as a part of the system into account, possible risk under the system operation identification with taken under consideration the time and cost 
factor. Designing of complex business systems is always associated with the risk that the system fails to reach the desired safety level and losses and damages shall be higher than the assumed acceptable level and the surrounding conditions may alter so much that the presumed respond measures and objectives of the system shall no longer be adequate.

Safety engineering, from the systematic point of view (Bertalanfy, 1973; Cempel, 2006; Klir, 1972; Szpytko \& Kocerba, 2008), predominantly deals with artificial systems that exhibit the following features:

- they are integrated, which means that all the system components are dedicated to one specific objective, which must be precisely established prior to the designing process starts,

- the system is large: system is made up of a large number of various components, performs a number of functions and is expensive,

- mutual interdependence between system components is significant (changes of one system variable affect a number of other system variables),

- system inputs are subject to stochastic stimulation,

- the system is partly automated: some of the system functions are still performed by human operators, but other ones are a subject of programming using dedicated tools.

Safety engineering deals with preparation of decisions dedicated to technical and/or organizational matters that include:

- analysis of the problem with consideration of all the essential internal and external interrelationships,

- definition of desired targets for the problem solution with respect to the required system safety level,

- disclosing of all the possible options for the possible final solution,

- comparison between specific solutions and rating them in terms of detrimental effect against the required expenditures,

- selection of the most advantageous option.

Definition of the engineering system on the subject of research comprises two basic operations: quantization and simplification of the system. Quantization consists of subdividing of the system into its elementary components (parts) and establishing of quantitative interrelationships of such elementary units. On the other hand, simplification of any system remains the art of engineering as it bases, to the substantial degree, on the engineer's intuition.

Major issues on system safety engineering systematic formulation stage include selection of suitable criteria (criterion), seeking for feasible solutions, consideration to intangible matters, taking the human factor into account, introduction of risk and time-induced deterioration. Designing of complex systems is always associated with the risk that the system fails to reach the desired safety level and both losses and damages shall be higher than the assumed acceptable level, as well as the surrounding conditions may alter so much that the presumed respond measures and objectives of the system shall no longer be adequate. 
During the systematic system analysis process, three different objectives of systematic analysis are possible to distinguish: for the primary real system under consideration, for the virtual system developed based on the primary system and system carried out analysis. The next stage include definition of the system on the subject of research with further specification of such system, supported by analysis of the system structure and behaviour and ideas leading for improvements and corrections of the existing system (e.g. integration of subsystems and components) with above implementation as the last step. Definition of the system on the subject of research includes the following tasks:

- checking whether specification of the system objectives is correct,

- selection of the system components,

- selection of the system surrounding components,

- selection of essential links between system components,

- selection of essential links between the system and its surrounding,

- deployment of a graphic image of the system,

- development of matrix-based representation of the system,

- other forms of system representation.

Moreover, it is highly desirable to make the decision whether system components will deemed as actions or organization units, select the abstraction degree and determine the system components where the decision-making process takes place, as well as those where only simple information processing occurs, and finally find out how make description of the system fully or partly automatic at least. The large system analysis from safety attention needs support computer-based techniques.

The important step of any operation system analysis focusing especially on safety problems are system structure and behaviour as well as interaction between specified elements. Analysis of the safety system structure and behaviour should provide answers to the following questions:

- what is the system nature and objectives?

- what is the system structure and how it corresponds to its objective and what is the system behaviour?

- why does the system behaviour fail to be in line with the initial assumptions?

- is it possible to improve the system operation and how to achieve this?

- how shall the suggested improvements affect the system behaviour?

\section{Designing of Safety Systems}

Development of safety systems, based on real circumstances (on an existing system), is started from a systematic search for real equivalents to the applied terminology, which is already known from systematic analysis. Then the system layout should be present in a perceivable form (verbal definition, tabularized scheme, graph, decision diagram and /or computer presentation, etc.). The system development process incorporates definition of components and interconnections among them. Some selected factors are significant, whereas other are neglecting. Possible interferences between system components must be taking into account, as well as sequences and frequencies of system processes and events are a subject of 
analyzing. Then categorization of the engineering problem must be carrying out, but unity of terminology must permanently being keeping in mind.

Systematic approaches have a direct input to the mental activities of researchers in the field of safety engineering in relatively fixed sequences that comprises the following steps:

- identification and diagnosis of a research subject which have been extracted from the entire system,

- system identification, definition of the system on real and objectively existing circumstances and environment,

- representation of a real system by means of its model (meta-system designing),

- quantization of characteristics attributable to the designed system,

- algorithmization and experimental modelling (solutions, calculations),

- analysis and interpretation of result obtained from systematic studies,

- analysis of implementation opportunities associated with result obtained from systematic studies.

The above classification is only an arbitrary assumption.

So-called safety systems should met the following requirements:

- be capable to correctly perform their functions with no conflicts with the surrounding environment,

- provide sufficient controllability and maximum possible degree of automation and computerization of operator's activities,

- guarantee that technical durability, economic lifetime and innovative qualities of he facilities shall be employed in reasonable degree,

- make sure that environmental requirements shall be met,

- be secured against unauthorized and undesired access to the facilities,

- be furnished with ergonomic technical solutions, including easy control and operation facilities,

- guarantee that the facilities are ready to perform their function in fault-free manner wit due regard to technical condition of the facilities as well as physical and mental status of operators,

- enable current and permanent insensitivity to exposure to internal and external harmful factors, tolerance to inherent faults and operator's errors,

- be equipped with technical and medical neutralizing and counteracting means as well as measures for elimination of effects of critical disasters,

- meet requirements to insure the facilities against damages and operators against third-party responsibility as a consequence of failures and injures to operators and damages to the facilities and goods.

Methodological development of safety systems should give answers to the following questions: Who claims needs to initiate safe execution of the assignment with system use? Whose needs related to system safety assurance must be fulfilling? Whose point of view is taking into account when the needs for system safety assurance are considered? How many viewpoints can be respect when the need for system safety assurance is considered? What is the position of system safety assurance in the hierarchy of organization's needs? When fulfilling of the 
system safety assurance needs should start and how long it should last? Which techniques for system safety assurance are applied, and. which methods and expenditures are anticipated? What external circumstances are predictable during system assurance process? Which disturbances and which conductive factors are expected? What are constraints related to safety assurance means and methods? How make the system assurance process effective? What methodological and subject matter reasonable approaches are to be applied? How to balance capabilities and demands for safety assurance means?

Designing process of safety systems requires expenditures (what kind) and material means (how much) which are involved into the safety assurance area, as well as the approaches to fulfil the overlooked need with use the system (what) and items details (what kind: material securing means, technical or medical services or methods) which are included into system safe completion - Figure 3. Other actions must concentrated on clients that are responsible to specify the system safety assurance applied and decides upon functions of safety means and the method in which these means enable safety assurance. Moreover, on unit/ man which has right to sets up system operation and acceptance criteria for safety means and verifies whether the selected safety means conform to the regulations and requirements (checking usability, functionality, ergonomic features and others). The operation process of the system is connecting with maintenance. Also essential is knowledge related to the manner of further operation and maintenance of the system safety (how much is needed, how to measure the demand), as well as requirements which are necessary to achieve top efficiency and inherent uniformity of the system safety (are reusable or disposable safety means to be used and what is the anticipated lifetime thereof).

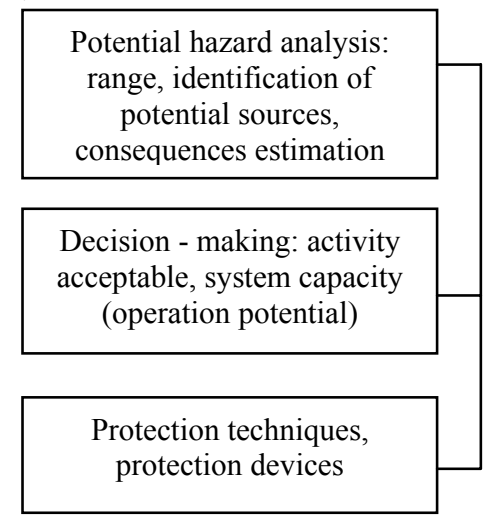

Fig. 3 Scheme of safety systems designing

Maintenance phase is dominated by the preventive type approach and decisionmaking based on system technical state or expressed operational potential. The key matter is proper activities control of special services. The above implementation needs to be continuously monitoring the technical state of the system and its 
degradation. To analyze the system degradation processes the cause - effect methods are useful: FMECA (Failure Modes and Effect Analysis), HAZOP (Hazard and Operability studies), FTA (Fault-Tree Analysis methods).

During the design process, it is necessary to take under consideration that the system never reaches system safety assumption and losses will be higher then planned, as well as environmental state of the system will change so far - so founded previously activities and targets of the system will be no more suitable.

\section{Transport safety supervision system}

Safety of transportation devices is a priority problem in exploitation, particularly for inspected one. Requirements placed to the device maker, as well as technological progress, make possible to improve constructions taking into consideration users (clients) needs and expectation. The device safety concept is drifting from a passive approach to mixed taking into account active and adaptation type of solutions. The above required system approach to device safety shaping, with taken into account distinguished devices' subsystems, integration of all actors engaged into the operating process (people and loads movements, impact with surrounding), continuous and evolutionary character. The device safety is reached in all devices' life phases and is verified in operation phase (exploitation is including operation and maintenance).

Obtained user needs in a field of safety is in practise difficult to obtain, because the impacts have a complex character, the device unit costs is very high, and mostly affects the unit production. It is the reason why in practise special attention is focusing on integrated undertaken which rationalise exploitation safety of the device in a particular environmental conditions, as well as modernisation type (reengineering approach) based on such fields of activity like: technology, data mining, management. To keep overlooked safety level the complex approach is necessary.

The market globalization places new challenges in the management of activities in particular in transportation activities. There are searching techniques make possible effective management of transportation systems, with taken safety and reliability into consideration. Such chances produce telematics technique (Szpytko, Jaźwiński, Kocerba, 2007). As the result of telematics used in different fields of man activities it is possible to reduce exploitation costs of technical devices. Techniques, which support telematics (e.g. software, hardware and tools), are rapidly improved. It is growing requirement on so-called intelligent transport service ITS type (Intelligent Transport Services) and dynamical type management of transportation devices DTM (Dynamic Traffic Management), both on large distances and at integrated automated manufactures.

The transport system is mostly composed from three categories of agents/ actors: device A, man-operator B (device B1, service/ maintenance B2, general coordinator/ management B3), safety subsystem C (in complex systems the total number of actors is equal to $\mathrm{N}$, e.g. $\mathrm{D}$ - surrounding). Between each actor exist 
specified relation/controls (Figure 4). For example between operator and device attributes' exists several correlations, for example: perception - information visualization, knowledge - monitoring, skills - operation realization ability, decision making ability - corrective auto-activity, reaction on external stimulus safety device and strength.

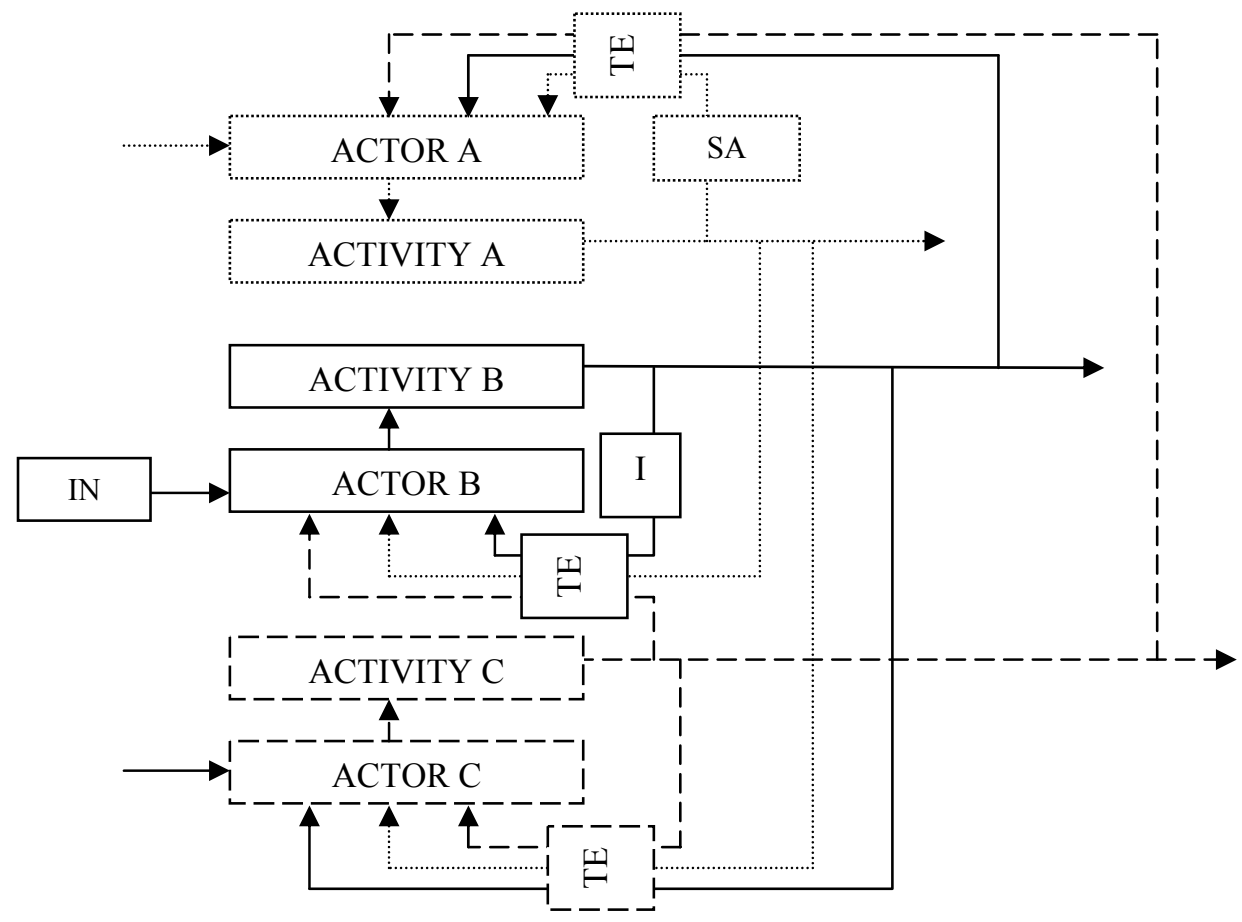

Fig. 4 The transport active knowledge model [Szpytko, 2004a]: I - knowledge and skills module, IN - inputs, SA - auto-corrective module, TE - telematic unit

Example expectations from the safety subsystem are as follows:

- recognition and signal of the device technical state,

- recognition and signal of the psychical and psychological operator predisposition,

- recognition and signal of the possible hazards coming from surroundings (e.g. anticollision sensors),

- passive safety (over- dimensioning of the subsystems),

- active safety: overloads limiter, active and oriented energy dissipation during undesirable events, intelligent based safety systems used sensors estimated acting forces and hand-worked special safety devices (e.g. airbags, safety belt, both acting force level sensitive),

- automatic undertaken emergency procedures under hazardous situations,

- signals devices addressed to the other user operating at the same place (e.g. sound signals, visual signals, added light). 
Each agent is an object of supply and controls. Man-operators are equipment with modules of knowledge and skills I (with use of own in-build sensors), which make possible auto-correction of done controls as the results of undertaken activities. Moreover, the device, depending on automation level, may be equipped in autocorrective module SA (self-acting). The output products of activities undertaken by individual agents are shaping for decision-making needs in quality module socalled telematics. Telematics TE is a quality module, which help management:

- to get exit products generated by agents which have been taken part in directed undertakings,

- base on quantity and qualitative assessment of exit products to generate integrate products (including safety indicators),

- to extract conclusions which help to compose dedicated input controls and implement them in practice.

A significant purpose to use telematics in practice is to optimize activities (or combined activities) as the result of more effective getting and utilization of possible information (activities accompanying data). Telematics is based on techniques in the field of informatics (Information Technology), vision sources (optoelectronics), automation and telecommunication and decision making approach.

Activities D implemented by $i$-th agent are possible to present by dependence:

for $\mathrm{i}=1 \ldots . \mathrm{N}, \mathrm{k}=1 \ldots \mathrm{p}, \mathrm{j}=1 \ldots \mathrm{r}$

$$
\mathrm{D}(\mathrm{i})=\mathrm{f}[\mathrm{D}(\mathrm{i}, \mathrm{k}, \mathrm{j}), \mathrm{T}, \Delta \mathrm{T}, \mathrm{M}, \Delta \mathrm{M}, \mathrm{SK}, \Delta \mathrm{SK}]
$$

where:

D - activity,

$\mathrm{D}$ (i) - activity $\mathrm{D}$ implemented by $i$-th agent,

$\mathrm{D}(\mathrm{i}, \mathrm{k}, \mathrm{j}) \quad-j$-th category of information accompanying of $k$-th category of activity D realized by $i$-th agent including safety indicators (which are describing system safety feature),

$\mathrm{T} \quad-$ time, time delay $\Delta \mathrm{T}$,

$\mathrm{M}=\mathrm{f}(\mathrm{x}, \mathrm{y}, \mathrm{z})$ - operation space 3D type and her parameters, change of space parameters $\Delta \mathrm{M}$,

SK - internal type connections concerning the object activity, change of connection $\Delta \mathrm{SK}$,

$i$-th agent which is implemented definite activities,

$k$-th category of activity realized by agent,

$j$-th category of information as the result of activities put into practice by agents.

The formula $\mathrm{D}(\mathrm{i})$ determine that $\mathrm{i}$-th agent (which possess specified knowledge and skills) has at owns disposal information accompanying realization of $k$-th category activities D oriented on load and/or man with consequences expressed with $j$-th information, taken into consideration safety indicators. The system activity is 
started and finished by agent B (operator) based on external information IN or/and own knowledge and skills. Information generated, as the result of activity of particular agent, can be available to him and others agents with the time delay $\Delta \mathrm{T}$ or are their lack. Information lack or receiving them with no acceptable time delay $\Delta \mathrm{T}$ be effective with no accurate (or without) decision making by the agent.

\section{Final Remarks}

We can suppose that presented engineering system features can be useful in selection of devices working in external conditions, favourable to realization the defined working tasks. The definite meanings are playing the interactions between main features of man - machine - surroundings: dependability is conditioning safety and effectiveness, durability maintains dependability, safety and effectiveness, adequacy is conditioning all positive outputs of described features of man - machine set (Fig.5).

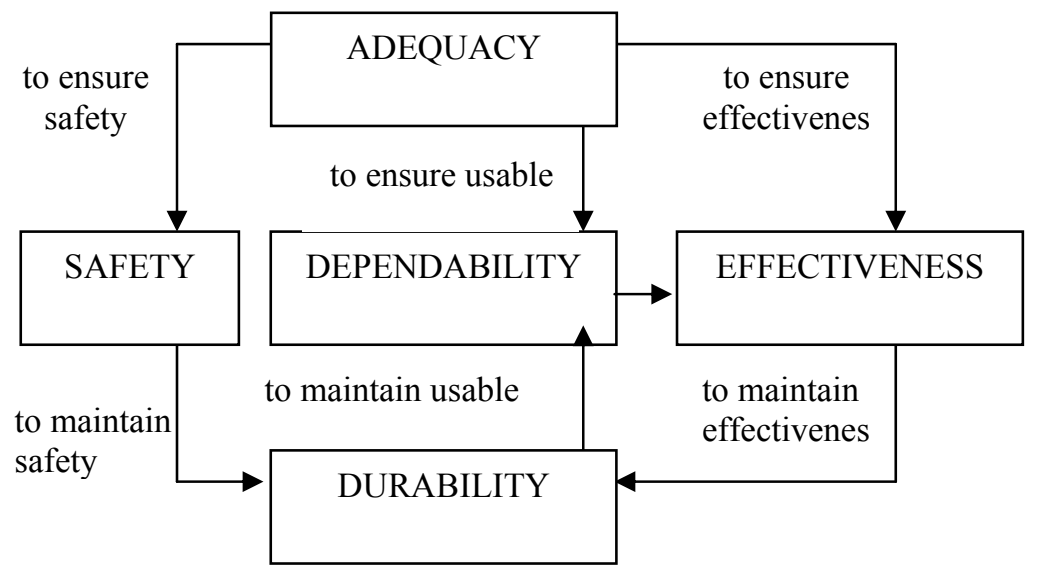

Fig. 5 Relation between main operation features in man - machine set

Scientific disciplines related to the systematic approach to safety issues have one common subject - the investigated system. They also use similar methods that are employs for research activities: interdisciplinary approach, broad metal horizon, ability to overcome formal borders between specialized disciplines and individual features of business and administrative organizations. Results the known references on safety engineering, the systematic approach to safety assurance can be still consider as the most suitable method and should be subject to further development and investigation.

Analysis of today progress in any complex system including safety problems and needs makes possible the following conclusions: 
1. further evolution into more complex system where human is playing essential part,

2. are overlooking new solutions together increasing safety and reliability of system composite as man - machine set,

3. solution evolution of remote warning before possible systems threats and dangers,

4. more stronger integration of systems structures and activities, systems follow up,

5. more stronger improvement of preventive approach to maintenance process,

6. better system set process understanding (not only analysis of system with use the Fault Tree Analysis method) in result of investigation of system exploitation potential changes and his invariability (the intelligence, adaptation),

7. developing improvements in methods and tools focusing on decision making process with use of man - machine interfaces,

8. much more stronger integration of man - machine - environment set,

9. progressing in shaping system safety and reliability taking into account lifephases of the man-machine set.

Major issues on safety engineering in practice include selection of suitable tolerance zones of selected key operation parameters of the system, taking the human factor as a part of the system into account, and possible risk under the system operation identification with taken under consideration the time and cost factor. Designing of complex business systems is always associated with the risk that the system fails to reach the desired safety level and losses and damages shall be higher than the assumed acceptable level and the surrounding conditions may alter so much that the presumed respond measures and objects of the system shall no longer be adequate.

\section{References}

1. Aven T., Vinnem J.E. (Eds.): Risk, Reliability and Societal Safety. Taylor \& Francis Group, London, 2007.

2. Avizienis J.G., Larie B., Randel: Fundamental concepts of dependability. Newcastle University, Report no.CS-TR-739, Newcastle, 2000.

3. Bertalanfy von L.: General Systems Theory. Brazilier, NY, 1973.

4. Borgon J., Jaźwiński J., Sikorski M., Ważyńska-Fiok K.: Niezawodność statków powietrznych. ITWL, Warszawa, 1992.

5. Cempel C.: Teoria i inżynieria systemów (Theory and Engineering of Systems). ITE, Radom, 2006.

6. Elsayed A.E.: Reliability engineering. Addison Wesley Longman Inc., Reading, 1996.

7. Fr. von Gottl - Ottilienfeld: Wirtschaft und Technik. Grundigs der Socialekonomik, Tybinga, 1932. 
The Man-Machine Type Systems Modeling Approach

Metodyka modelowania układów typu człowiek - maszyna

8. Jaźwiński J., Borgoń J.: Niezawodność eksploatacyjna i bezpieczeństwo lotów. Wydawnictwo Komunikacji i Łączności, Warszawa, 1989.

9. Jaźwiński J., Ważyńska-Fiok, K.: Bezpieczeństwo systemów. PWN, Warszawa, 1993.

10. Klir G.J.: Trends in General Systems Theory. Prentice Hall, NY, 1972.

11. Mazur M.: Terminologia techniczna. WNT, Warszawa, 1961.

12. Mourbray J.: Reliability Centered Maintenance. Butterworth-Heinemann Ltd, Oxford, 1991

13. PN-77/N-04010, Wybór wskaźników niezawodności.

14. Puszkin W.G.: Problema nadeżnotsi. Izdatelstwo Nauka, Moskwa, 1971.

15. Saleh J.H., Marais K.: Highlights from the early (and pre-) history of reliability engineering. Reliability Engineering \& System Safety, 91 (2), 249-256, 2006.

16. Sklet S.: Safety barriers: Definition, classification, and performance. Journal of Loss Prevention in the Process Industries, 19 (5), 494-506, 2006.

17. Smalko Z., Szpytko J.: Kierunki i perspektywy rozwoju transportu w aspekcie globalizacji rynku. Inżynieria Maszyn, s. 14 - 20, v.8, z.1, 2003.

18. Smalko Z.: Pięć podstawowych pojęć $w$ technice. Komitet Naukoznawstwa PAN, PAN, Warszawa, 1987.

19. Smalko Z.: Podstawy projektowania niezawodnych maszyn $i$ urzadzeń mechanicznych. PWN, Warszawa, 2005.

20. Smalko Z.: Wybrane problemy inżynierii bezpieczeństwa. Materiały 36 Szkoły Zimowej Niezawodności, s. 298-297, PAN, Szczyrk, 2008.

21. Szpytko J., Jaźwiński J., Kocerba A.: System koordynacji działania rozproszonych środków transportu (Management system of distributed transport devices). Prace Naukowe, Transport, z 63, s.249-256, Oficyna Wydawnicza PW, Politechnika Warszawska, Warszawa, 2007.

22. Szpytko J., Kocerba A.: Wybrane aspekty bezpieczeństwa $i$ niezawodności rozproszonych środków transportu. Monografia, Biblioteka Problemów Eksploatacji, ITE, Kraków - Radom, 2008.

23. Szpytko J.: Ksztattowanie procesu eksploatacji środków transportu bliskiego. Monografia, Biblioteka Problemów Eksploatacji, ITE, Kraków - Radom, 2004a.

24. Szpytko J.: To increase systems safety and reliability by better man machine interface. Proceedings on 8th IFAC International Symposium on cost oriented automation - affordable automation systems, XII Convencion y Expo Internacional - Informatica 2007, La Habana, 2007a.

25. Titus, Lucretius, Carus: O naturze rzeczy. Ludowa Spółdzielnia Wydawnicza, Warszawa, 1995.

26. Tobias P.A., Trindade D.: Applied reliability. Van Nostrand Reinhold, New York, 1986. 


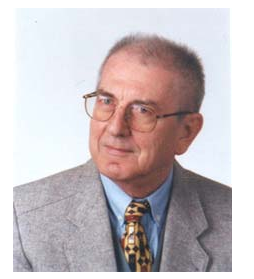

Prof. dr hab. inż. Zbigniew SMALKO, professor of the Air Force Institute of Technology, Warszawa, as well as the University of Technology, Faculty of Transport. Specialist in reliability safety and maintainability of technical transport systems, operation problems of transport systems and devices. Author and co-author of more then 200 scientific publications. Member of: Polish Academy of Science (PAN) Transport Committee, PTBiN, ERN SAFERLENET, ETNiŚT; Editor in Chief of Archives of Transport, Chair of Winter Schools of Reliability PAN. Organisator and member of several scientific and programme committees of international and national conferences and symposiums.

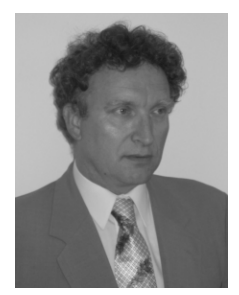

Prof. Dr hab. CEng. Janusz SZPYTKO, AGH University of Science and Technology, Faculty of Mechanical Engineering and Robo-tics. Specialist in designing and exploitation of transport systems and devices, automatics, safety and reliability, monitoring and diagnostics, decision making systems, telematics. Author or co-author of more then 300 publications, both in Polish and English. Member of: STST KT PAN, TC IFAC, SEFI, ISPE, PTD, PTB, PSRA, ISA, SITPH and others. Visiting professor at the universities in: UK, France, Canada, Italy, Greece, Canada, Laos. Coordinator and member of several R\&D projects both national and international. Organizer and member of several scientific and programme committees of international and national conferences and symposiums. 